\title{
PERENCANAAN PENGEMBANGAN USAHA TANI PERHUTANAN KERAKYATAN DI DAERAH TANGKAPAN GUMBASA BAGIAN HULU, DONGGALA, SULTENG (Studi Kasus Sub-sub Daerah Aliran Sungai Toranda)
}

\author{
Oleh: Hariyono \\ Sekolah Tinggi Ilmu Pertanian Belitang \\ Jln.Kampus Pertanian No.3 Belitang Kab.OKU Timur Prov.Sumatera Selatan \\ e-mail: hariyono.ss@gmail.com
}

\begin{abstract}
The Research amed to determind policy introduce social forestry management development as a sustainable in Gumbasa Catchment Area - Donggala - Central Sulawesi. Research by case study from Subs Toranda Watershed, included: social preference analysis for social forestry management development by MPE Approach, financial feasebility analysis by social economic method approach and soil erosion analysis by trial erosion approach, in cacao land use monoculture (traditional) 9\% slope and 37\%, cacao land use by SUPK/SFMU 10\% slope and 38\% and open land use 5\% slope at all each $3 \mathrm{X}$ so 15 sample unit. The result that social preference to choice commodity priorities farm develop SUPK/SFMU are; 1) Jati, 2) Mahoni3) Nantu/Nyatoh, 4) Cempaka, 5) Ebony, 6) Kemiri, 7) Avocado, Farm financial feasibility SUPK/SFMU by B/C ratio $=4,92$ and IRR $=40 \%$ higher than cacao farm monoculture by B/C ratio 3,01 and IRR 35\%. Cacao land use monoculture, SUPK/SFMU, open land use with erosion.

Rate more from social erosion what can be accept (TSL). Land use erosion y cacao land use SUPK/SFMU can be reduce soil erosion 77,2\% on slope "agak miring" and 74\% on slope "agak curam" than cacao land use monoculture.
\end{abstract}

Key words : SUPK/SFMU, Social preference, Financial Feasebilty

\section{PENDAhUluAN}

Daerah Tangkapan (DTA) Gumbasa merupakan salah satu kawasan DAS Palu yang merupakan DAS prioritas di Indonesia (Arsyad, 2007). Terganggunya ekosisterm hutan yang terdapat di Taman Nasional Lore-Lindu (TNLL), hutan lindung, dan hutan produksi disebabkan alih fungsi dekitar 20.000 Ha hutan (sekitar 23\% dari luas total DTA Gumbasa baigan hulu) menjadi areal budidaya kakao dalam kurun waktu 20 tahun terakhir. Konservasi tanah dan air perlu segera diwujudkan sebagai bagian dari perencanaan pengembangan lahan pertanian berkelanjutan di DTA Gumbasa bagian hulu. Pengelolaan lahan budidaya kakao pola agroforestry merupakan alternatif pemecahan masalah yang dianggap efektif untuk mengatasi semakin memburuknya ekosistem DTA Gumbasa bagian hulu. (Widjajanto, 2006a).

Golar (2007) berpendapat bahwa intensitas tekanan penduduk terhadap pemanfaatan sumber daya lahan dan hutan di TNLL dan daerah daerah penyangganya lebih banyak dipengaruhi oleh adanya intervensi ekonomi pasar dibandingkan perspektif social-budaya. Revitalisasi kelembagaan masyarakat yang berperan dalam pemanfaatan sumber daya lahan dan hutan merupakan kunci keberhasilan pembangunan konservasi di daerah tersebut.

Pendapatan keluarga yang rendah (kurang dari 1 US\$/jiwa/hari) menyebabkan rendahnya masukan (input) usaha tani. Kondisi yang demikian sejalan dengan waktu menyebabkan terjadinya degradasi lahan pertanian. Fluktuasi harga dan produksi kakao yang sulit diprediksi merupakan akar permasalahan kesulitan melakukan perencanaan pengembangan komoditas kakao di daerah penyangga Taman Nasional LoreLindu (Thaha, 2001; Rauf, 2004).

Kompleksitas permasalahan ekologi, ekonomi, dan sosial menyebabkan terjadinya ketidakpastian dalam perencanaan pengelolaan sumberdaya lahan (FAO dan UNEP, 1999; Gao et al. 2003). Sjarkowi (2007).

Menyatakan bahwa paradigma pengembangan pertanian yang bersifat subsisten pada hakekatnya perlu diubah menuju sistem usahatani yang mengacu pada konsep satuan usaha perhutanan kerakyatan (SUPK). Rekayasa hutan dan rekayasa sosial merupakan jawaban dari pertanyaan bagaimana konsep SUPK dapat dikembangkan.

Permasalahan kebijakan konservasi dan tata duna lahan dapat diselesaikan secara bersama-sama melalui perencanaan secara lintas disiplin ilmu pengetahuan dan 
lintas sektor. Tujuan penelitian adalah menentukan arahan kebijakan pengembangan usahatani pola perhutanan kerakyatan yang berkelanjutan di DTA Gumbasa, Donggala, Sulawesi Tengah.

\section{METODOLOGI PENELITIAN}

\section{Lokasi dan Waktu Penelitian}

Lokasi penelitian dilakukan di Sub DAS Toranda, DTA Gumbasa Palu hulu, Donggala, Sulawesi Tengah. Penelitian melalui tiga pendekatan, yaitu: 1) analisis preferensi pengembangan usahatani perhutanan kerakyatan, 2) pengukuran erosi tanah aktual, dan 3) survei usahatani pada pola perhutanan rakyat.

\section{Metode Pengumpulan Data}

Pengumpulan data untuk analisis preferensi pengembangan usahatani perhutanan kerakyatan dilakukan melalui tahapan sebagai berikut: 1) menentukan kriteria penilaian, dan 2) menentukan bobot dan nilai alternatif, dan 3) focus group discussion (FGD).

Tahap pertama, penelitian dilakukan untuk menentukan kriteria penilaian dan alternatif melalui kegiatan diskusi dari para pihak pemangku kepentingan (stakeholders) yang dipilih secara purposive terdiri dari pihak-pihak Balai Pengelolaan DAS Palu-Poso; Dinas kehutanan propinsi Sulawesi Tengah; Balai Taman Nasional Lore-Lindu; Universitas Tadulako; Bappeda Propinsi Sulawesi Tengah; LSM The Nature Conservacy; Dinas Kehutanan dan Perkebunan Kabupaten Donggala; Dinas Pertanian, Perkebunan, dan Peternakan Sulawesi Tengah; Kelompok Tani Fajar Kakao Desa Bahagia Kecamatan Palolo.

Tahap Kedua, menentukan nilai bobot dan kriteria melalui diskusi secara perorangan dengan menggunakan daftar isian yang telah memuat kriteria dan alternatif komoditas pilihan. Pemberian bobot dan nilai alternatif didasarkan atas metode skoring dengan skor antara 1 hingga 9. Skor 1 menyatakan bobot/nilai alternatif yang terenda, sedangkan skor 9 menyatakan bobot/nilai skor tertinggi.

Tahap ketiga, menentukan hasil akhir penilaian bobot dan kriteria terhadap prioritas preferensi komoditas yang dikembangkan dan usaha perhutanan kerakyatan yang dilakukan melalui diskusi stakeholders dengan tujuan melakukan koreksi terhadap hasil keputusan yang telah ditentukan sebelumnya.

Pengumpulan data untuk tujuan pengukuran erosi tanah aktual dilakukan melalui pengukuran secara langsung di lapangan yang meliputi data curah hujan harian, aliran permukaan, dan jumlah tanah tererosi. Data iklim pada saat penelitian didapatkan dari Balai Pengelolaan DAS (BPDAS) Palu-Poso. Erosi tanah aktual diukur pada setiap plot pengukuran erosi tanah berukuran 2x6 meter yang diulang sebanyak 3 kali dalam setiap perlakuan. Penentuan lokasi pembuatan plot pengukuran erosi tanah ditentukan secara purposive berdasarkan lahan dominan di daerah penelitian, yaitu: penggunaan lahan kakao pada kelerengan 9\%, penggunaan lahan kakao pada kelerengan 38\%, kakao pola agroforestry pada kelerengan $10 \%$, kakao pola agroforestry pada kelerengan $37 \%$ tanah terbuka pada kelerengan 5\%. Secara keseluruhan terdapat 15 unit plot percobaan.

Pengumpulan data usahatani dilakukan berdasarkan teknik pengambilan sampel secara acak terstratifikasi (stratified random sampling). Stratifikasi dilakukan berdasarkan satuan administrasi rukun tetangga (RT), sedangkan sampel responden pada setiap RT ditentukan secara acak. Jumlah sampel responden pada setiap RT ditentukan sebanyak 9 keluarga sehingga secara keseluruhan dari 5 RT terdapat 45 responden.

Data responden stakeholders yang digunakan dalam analisis penentuan referensi pengembangan komoditas usahatani perhutanan kerakyatan ditentukan berdasarkan nilai modus, sedangkan metode analisis data didasarkan pada metode perbandingan eksponensial (Marimin, 2004).

Analisis data erosi tanah dilakukan melalui pengukuran berat tanah kering oven pada setiap hari kejadian hujan di setiap plot pengukuran erosi. Curah hujan harian dan limpasan permukaan diukur untuk mengetahui korelasi antara setiap variable penelitian. Analisis data dilakukan berdasarkan metode analisis regresi linier berganda (Cochran, 1991). Laju erosi tanah yang dapat ditoleransi atau tolerable soil loss (TSL) di daerah penelitian ditentukan berdasarkan hasil penelitian terdahulu (Widjajanto, 2006).

Analisis kelayakan finansial pada tipe penggunaan lahan kakao monokultur dan pola satuan usaha perhutanan kerakyatan (SUPK) dilakukan dengan menggunakan teknik analisis net present value (NPV), net benefit-cost ratio (BCR), dan internal rate of return (IRR) (Soekartawi et al ., 1986).

\section{HASIL DAN PEMBAHASAN}

\section{Penetapan Komodias Prioritas}

Berdasarkan hasil diskusi dengan responden untuk menentukan preferensi pengembangan komoditas usaha perhutanan kerakyatan (tabel 1) didapatkan pemasaran produksi, keuntungan ekonomis, dan minat masyarakat usahatani perhutanan kerakyatan mempunyai bobot tertinggi dalamm penilaian, hal tersebut mengindikasikan bahwa orientasi agribisnis merupakan tujuan utama masyarakat untuk berusahatani.

Selanjutnya, kebutuhan kayu lokal dan kesesuaian lahan mempunyai urutan yang kedua. Penguasaan 
teknologi kehutanan dan kebiasaan bertanam mempunyai urutan kepentingan yang paling rendah. Kurangnya industry bidang kehutanan didaerah menyebabkan rendahnya penilaian terhadap kriteria penguasaan teknologi hasil hutan. Amar (2002) menyatakan behawa secara cultural masyarakat di Kabupaten Donggaka mempunyai kebiasaan melakukan budidaya kakao. Pola produksi pertanian subsisten melalui teknik bercocok tananm tradisional menyebabkan terjadinya kecenderungan produksi kakao yang semakin menurun.

Tabel 1. Penetapan Kriteria, Bobot, dan Nilai Alternatif Komoditas Pengembangan Usahatani Perhutanan Kerakyatan.

\begin{tabular}{|l|l|l|l|l|l|l|l|l|l|}
\hline No & Kriteria & Bobot & A & B & C & D & E & F & G \\
\hline $\mathbf{1}$ & Kebutuhan Kayu Lokal & 7 & 7 & 7 & 9 & 7 & 6 & 3 & 3 \\
\hline $\mathbf{2}$ & Pemasaran Produksi & 9 & 7 & 7 & 9 & 7 & 7 & 5 & 5 \\
\hline $\mathbf{3}$ & Keuntungan Ekonomis & 9 & 9 & 3 & 9 & 9 & 9 & 4 & 4 \\
\hline $\mathbf{4}$ & Penguasaan Teknologi & 5 & 5 & 5 & 5 & 5 & 5 & 7 & 7 \\
\hline $\mathbf{5}$ & Kesesuaian Lahan & 7 & 7 & 5 & 7 & 7 & 5 & 7 & 7 \\
\hline $\mathbf{6}$ & Minat Berusahatani & 9 & 9 & 3 & 9 & 9 & 9 & 5 & 3 \\
\hline $\mathbf{7}$ & Kebiasaan Bertanam & 3 & 3 & 3 & 3 & 5 & 5 & 5 & 5 \\
\hline
\end{tabular}

A; Nantu/Nyatoh; B: Eboni; C: Jati; D: Mahoni; E: Cempaka; F:Kemiri; G:Alpukat

Bersadarkan penialaian prefensi pengembangan komoditas usaha perhutanan kerakyatan (Tabel 2) didapatkan hasil bahwa prioritas masyarakat untuk menanam jati (Tectona Grandis) mempunyai urutan tertinggi, selanjutnya diikuti oleh mahoni (Switenia Macrophylla), nantu/nyatoh (Palaquium sp), dan cempaka (Michelia Cempaka), Sjarkowi (2007) menyatakan bahwa pengembangan usaha perhutanan kerakyatan sesuai untuk diterapkan pada orientasi bisnis terpadu secara makro kewilayahan maupun secara mikro melalui sistem kemitraan.

Tabel 2. Penilaian Prioritas Preferensi Masyarakat Terhadap Pengembangan Komoditas Usahatani Perhutanan Kerakyatan.

\begin{tabular}{|l|l|l|}
\hline Komoditas & Nilai MPE & Prioritas \\
\hline Jati (Tectona grandis) & 1.167 .871 .131 & 1 \\
\hline Mahoni (Switenia macrophylla) & 816.844 .921 & 2 \\
\hline Nantu/Nyatoh (Palaquium sp.) & 816.844 .823 & 3 \\
\hline Cempaka (Michelia campaka) & 815.555 .896 & 4 \\
\hline Eboni (Diospyros celebica Bakh) & 41.297 .793 & 5 \\
\hline Kemiri (Aleurites mollucana) & 5.011 .056 & 6 \\
\hline Alpukat (Persea Americana) & 3.077 .614 & 7 \\
\hline
\end{tabular}

Di lain pihak, penanaman eboni mempunyai prioritas yang terendah. Karena daur panen yang relatif lama (>30 tahun) sehingga preferensi masyarakat untk menanam komoditas tersebut rendah. Penanaman MPTs (multi purpose trees species) seperti kemiri dan alpukat merupakan prioritas yang paling rendah disebabkan oleh rendahnya nilai manfaat kayu dan ekonomis komoditas tersebut bagi masyarakat. Widjajanto (2006b) menyatakan bahwa penilaian preferensi masyarakat terhadap usahatani kakao memiliki prioritas tertinggi di DAS Gumbasa bagian hulu sedangkan usahatani perhutanan mempunyai prioritas terendah. Rendahnya penilaian preferensi usahatani disebabkan karena alternatif yang digunakan dalam penilaian adalah usahatani subsisten melalui pengembangan budidaya agroforestry kakao dan gamal untuk produksi kayu bakar, meninjau dari hasil penelitian tersebut maka untuk tujuan praktis maka perencanaan pengembangan lahan budidaya kakao pola SUPK ditekankan pada penanaman sela komoditas jati, nantu/nyatoh, mahoni, kemiri dengan jarai tanam $3 \times 4$ m.

\section{Kelayakan Finansial}

Berdasarkan hasil analisis kelayakan finansial usahatani kakao monokultur dan SUPK (tabel 3) dinyatakan bahwa penerapan usahatani kakao pola SUPK mempunyai kelayakan finansial yang lebih tinggi $(\mathrm{BCR}=4,92 ; \mathrm{IRR}=0,40)$ dibandingkan dengan pola penanaman kakao pola tradisional/subsisten $(\mathrm{BCR}=$ 3,$01 ; \mathrm{IRR}=0,35$ ).

Tabel 3. Analisis Kelayakan Finansial Usahatani Kakao Pola Subsisten dan SUPK.

\begin{tabular}{|c|l|l|l|l|}
\hline Tahun & $\begin{array}{l}\text { Pendapatan } \\
\text { Usahatani } \\
\text { Kaka0 Pola } \\
\text { Subsisten }\end{array}$ & $\begin{array}{l}\text { NPV Usahatani } \\
\text { Kakao pola } \\
\text { Subsisten } \\
\text { (DF=0,18) }\end{array}$ & $\begin{array}{l}\text { Pendapatan } \\
\text { Usahatani } \\
\text { Kaka0 pola } \\
\text { SUPK(Rp/ha) }\end{array}$ & $\begin{array}{l}\text { NPV Usahatani } \\
\text { Kakao pola } \\
\text { SUPK } \\
\text { (DF= 0,18) }\end{array}$ \\
\hline 0 & -13.506 .139 & -13.506 .139 & -16738.0377 & -16.738 .037 \\
\hline 1 & -5.132 .500 & -4.349 .576 & -5.132 .500 & -4.349 .576 \\
\hline 2 & -5.132 .500 & -3.686 .082 & -5.132 .500 & -3.686 .082 \\
\hline 3 & -777.500 & -473.211 & -657.500 & -400.175 \\
\hline 4 & 4.576 .027 & 2.360 .264 & 4.847 .215 & 2.500 .140 \\
\hline 5 & 7.973 .652 & 3.485 .357 & 9.039 .592 & 3.951 .289 \\
\hline 6 & 13.412 .318 & 4.968 .346 & 14.736 .678 & 5.458 .930 \\
\hline 7 & 26.629 .049 & 8.359 .525 & 28.631 .271 & 8.988 .073 \\
\hline 8 & 31.520 .984 & 8.385 .785 & 33.920 .677 & 9.024 .195 \\
\hline 9 & 37.503 .454 & 8.455 .381 & 43.121 .422 & 9.721 .986 \\
\hline 10 & 38.331 .245 & 7.323 .739 & 191.527 .665 & 36.594 .131 \\
\hline 11 & 38.331 .245 & 6.206 .558 & 46.780 .720 & 7.574 .689 \\
\hline 12 & 38.331 .245 & 5.259 .795 & 51.056 .401 & 7.005 .935 \\
\hline 13 & 38.331 .245 & 4.457 .454 & 54.905 .309 & 6.384 .814 \\
\hline 14 & 38.331 .245 & 3.777 .503 & 54.905 .309 & 5.410 .859 \\
\hline 15 & 38.331 .245 & 3.201 .274 & 254.905 .309 & 21.288 .682 \\
\hline BCR & & $\mathbf{3 , 0 1}$ & & $\mathbf{4 , 9 2}$ \\
\hline (DF= & & & & \\
\hline $\mathbf{0 , 1 6})$ & & & & \\
\hline IRR & & 0,35 & 40 \\
\hline & & & & \\
\hline
\end{tabular}

Penanaman MPTs tanaman kemiri yang mulai menghasilkan produksi pada saat berumur 4 tahun. Selanjutnya pada tahun ke-10 mulai dilakukan pemanenan hasil kayu nantu/nyatoh dan mahoni. Pemanenan jati dilakukan pada tahun ke 15. Mappatoba dan Laapo (2001) menyatakan bahwa pengembangan sistem usahatani terpadu disarankan sebagai alternatif pengembangan model sistem usahatani pada daerah penyangga Taman Nasional Lore-Lindu. Rahman (2002) menekankan bahwa pengelolaan hutan di Kabupaten Donggala yang dilakukan secara tradisional menyebabkan rendahnya pendapatan petani hutan. 


\section{Kelayakan Ekologi/Lingkungan}

Berdasarkan hasil pengukuran erosi tanah aktual dan limpasan permukaan penggunaan lahan kakao pola tradisional pada kelerengan 9\% didapatkan hasil laju erosi tanah dan limpasan permukaan tertinggi berturutturutadalah $140 \mathrm{~kg} / \mathrm{ha} /$ hari dan $14 \mathrm{~m}^{3}$ /ha/hari yang terdapat pada intensitas hujan sekitar $34 \mathrm{~mm} / \mathrm{hari}$. (Gambar 1), sedangkan laju pada penggunaan lahan kakao pola tradisional pada kelerengan 38\% menunjukkan laju erosi tanah dan limpasan permukaan tertinggi berturut-turut adalah $170 \mathrm{~kg} / \mathrm{ha} / \mathrm{hari}$ dan $88 \mathrm{~m}^{3}$ /ha/hari (gambar 2). Laju erosi tanah yang terjadi pada penggunaan lahan kakao pola monokultur (tradisional) kelerengan 9\% dan 38\% secara berturut-turut adalah 314,09 ton/ha/musim dan 426,85 ton/ha/musim.

Berdasarkan hasil penelitian tersebut dapat dinyatakan bahwa laju erosi pada penggunaan lahan kakao berada diatas batas erosi tanah yang masih dapat ditoleransi (TSL). Widjajanto (2006) menyatakan bahwa batas TSL di daerah penelitian adalah 15,62 ton/ha/tahun.

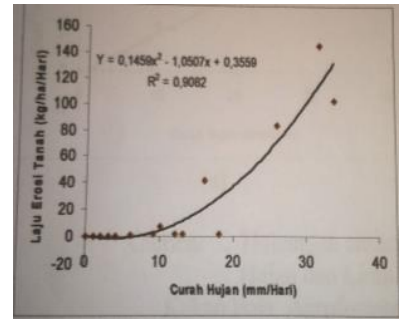

(a)

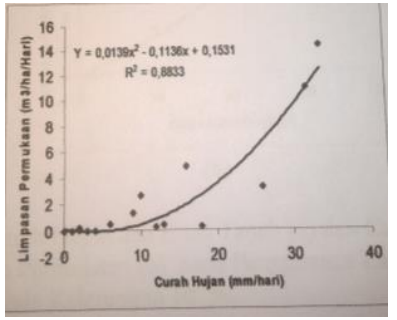

(b)
Gambar 1. Hubungan antara Curah hujan dan Erosi tanah (a) dan Curah hujan dan Limpasan permukaan (b) pada penggunaan lahan kakao pola tradisional dengan kelerengan $9 \%$

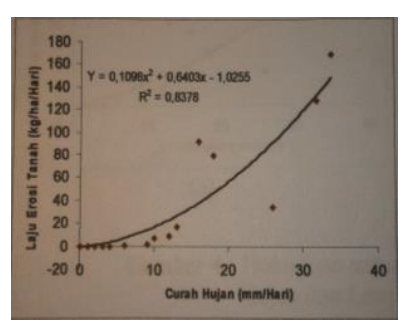

(a)

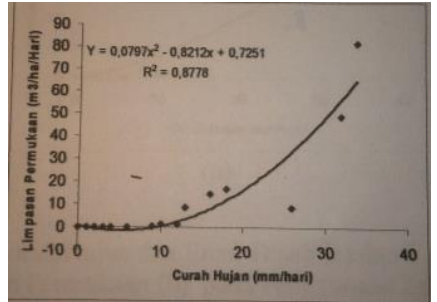

(b)
Gambar 2. Hubungan antara Curah hujan dan Erosi tanah (a) dan Curah hujan dan Limpasan permukaan (b) pada penggunaan lahan kakao pola tradisional dengan kelerengan 38\%

Berdasarkan hasil pengukuran erosi tanah aktual penggunaan lahan kakao pola agroforestry pada kelerengan $10 \%$ didapatkan hasil bahwa laju erosi tanah dan limpasan permukaan tertinggi berturut-turut adalah $22 \mathrm{~kg} / \mathrm{ha} /$ hari dan $6,3 \mathrm{~m}^{3} / \mathrm{ha} /$ hari yang terdapat pada intensitas hujan maksimum sekitar 34mm/hari. (gambar 3). Pengukuran erosi tanah akurat pada penggunaan lahan kakao pola agroforestry pada kelerengan $37 \%$ menunjukkan bahwa laju erosi tanah dan limpasan permukaan tertinggi berturut-turut adalah $40 \mathrm{~kg} / \mathrm{ha} /$ hari dan $25 \mathrm{~m}^{3}$ /ha/hari (gambar 4). Hasil pengukuran erosi tanah aktual pada tanah terbuka dengan kelerengan 5\% menunjukkan bahwa laju erosi tanah dan limpasan permukaan tertinggi berturut-turut adalah 540kg/ha/hari dan $140 \mathrm{~m}^{3} /$ ha/hari (gambar 5).

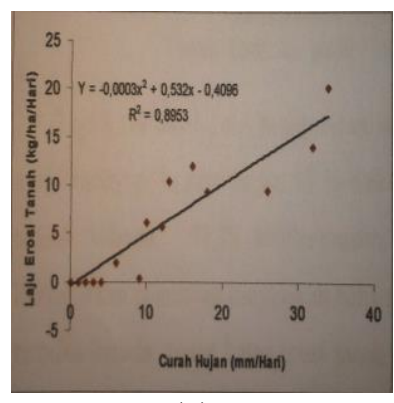

(a)

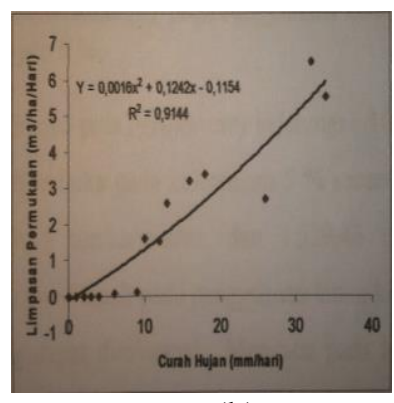

(b)
Gambar 3. Hubungan antara Curah hujan dan Erosi tanah (a) dan Curah hujan dan Limpasan (b) pada penggunaan lahan kakao pola Agroforestry pada kelerengan $10 \%$

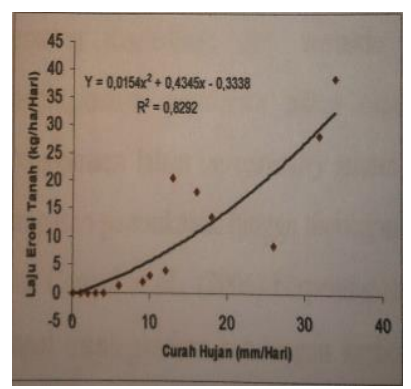

(a)

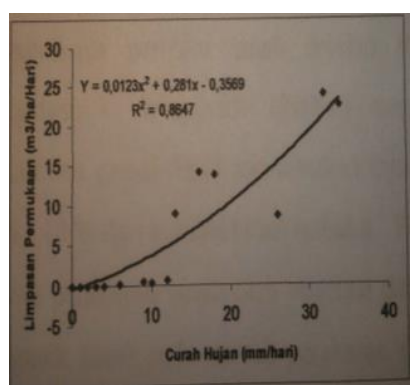

(b)
Gambar 4. Hubungan antara Curah hujan dan Erosi tanah (a) dan Curah hujan dan Limpasan permukaan (b) pada penggunaan lahan kakao pola Agroforestry pada kelerengan $37 \%$.

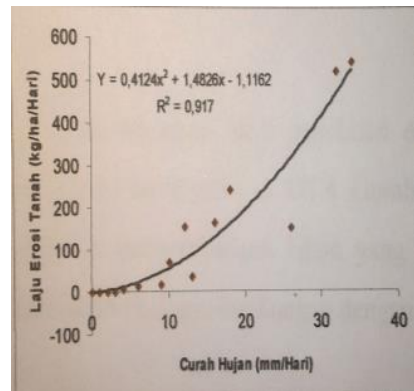

(a)

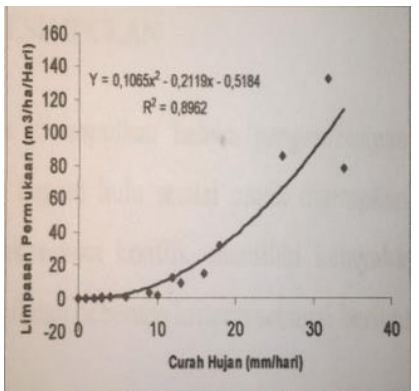

(b)
Gambar 5. Hubungan antara Curah hujan dan Erosi tanah (a) dan Curah hujan dan Limpasan permukaan (b) 
pada Penggunaan lahan tanah terbuka pada kelerengan $5 \%$

Laju erosi tanah pada penggunaan lahan kakao pola agroforestry kelerengan $10 \%$, kakao pola agroforestry pada kelerengan $37 \%$ dan tanah terbuka pada kelerengan $5 \%$ secara berturut-turut adalah sebesar 71,75 ton?ha/musim, 109,11 ton/ha/musim, dan 1.529 ton/ha/musim. Berdasarkan penelitian dinyatakan bahwa laju erosi tanah yang dapat ditoleransi. Mengacu pada hasil penelitian maka dinyatakan bahwa laju erosi tanah pada penggunaan lahan kakao pada pola agroforestry (SUPK) menurun sekitar 77,2\% pada kelerengan 9\% - 10\% (agak miring) dan $74,4 \%$ pada kelerengan $37 \%$ - 38\% (agak curam).

Laju erosi tanah dan limpasan permukaan semakin meningkat sejalan dengan semakin meningkatnya kelerengan tanah dan berkurangnya penutupan tanah oleh vegetasi. Kondisi tersebut disebabkan oleh semakin membaiknya perilaku tanah sejalan dengan semakin meningkatnya penutupan lahan lahan oleh vegetasi. Widjajanto (2006a) menyatakan bahwa penggunaan lahan agroforestry antara kakao dan gamal dapat menurunkan laju erosi tanah dan impasan permukaan hingga mencapai $8 \%-10 \%$ dari kondisi tanah terbuka. Wilts et al. (2004) dan Canqui et al., (2006) berpendapat bahwa penutupan tanah oleh vegetasi dan rotasi tanaman dapat meningkatkan kandungan karbon organic tanah pada daerah perakaran dan memperbaiki struktur tanah sehingga kandungan air tanah dapat dipertahankan untuk mencukupi kebutuhan tanaman. Lebih lanjut, Gicheru et al., (2004) dan Humberto et al., (2005) berpendapat bahwa perbaikan sifat fisik tanah dapat dilakukan melalui perbaikan pola tanam, pemberian bahan organic, pemupukan, dan pengolahan tanah.

\section{KESIMPULAN}

Berdasarkan hasil penelitian dapat disimpulkan bahwa pengembangan usahatani pola perhutanan kerakyatan di DTA Gumbasa bagian hulu sesuai untuk diterapkan sebagai arahan kebijakan pengembangan lahan yang tidak rawan konflik, memiliki kelayakan finansial, dan kesesuaian ekologis/lingkungan dengan penilaian beberapa kriteria sebagai berikut:

1. Aspek sosial: Preferensi masyarakat terhadap pengembangan usahatani perhutanan kerakyatan mempunyai urutan prioritas secara berturut-turut adalah jati (Tectona grandis), Mahoni (Switenia macrophyla), nantu/nyatoh (Palaquium sp.), cempaka (Michelia campaka), eboni (Diospyros celebica Bakh), kemiri (Aleurites mollucana), dan alpukat (persea Americana).

2. Aspek ekonomi: Kelayakan finansial usahatani kakao pola perhutanan kerakyatan (SUPK) mempunyai Nisbah Biaya-Manfaat (BCR) dan
Internal Rate of Return (IRR) yang lebih tinggi $(\mathrm{BCR}=4,92 ; \mathrm{IRR}=0,40)$ dibandingkan dengan usahatani kakao pola monokultur $(\mathrm{BCR}=3,01$; $\mathrm{IRR}=0,35$ ).

3. Aspek Ekologi/Lingkungan: penggunaan lahan kakao pola monokultur (tradisional), penggunaan lahan kakao pola perhutanan kerakyatan (SUPK), dan penggunaan lahan tanah terbuka mempunyai laju erosi yang lebih tinggi dari erosi tanah yang masih dapat ditoleransi (TSL). Laju erosi tanah pola (SUPK) menurun sebesar $77,2 \%$ pada kondisi lereng agak miring dan $74,4 \%$ pada kondisi lereng agak curam dibandingkan dengan penggunaan lahan kakao pola monokultur (tradisional).

\section{DAFTAR PUSTAKA}

Amar. 2002. Analisis Tingkat Spesialisasi Komoditas Pertanian Dalam Mendukung Perekonomian Daerah Kabupaten Donggala. J. Agroland 9 (2): 141-146. Arsyad, S. 2007. Konservasi Tanah dan Air. IPB Press. Bogor.

Canqui, H.B., R. Lal., W. M. Post., R.C. Izaurralde., and L.B. Owens. 2006. Corn Stover Impacts on Near-Surface Soil Properties of No-Till Corn in Ohio. Soil Sci. Soc. Am. J. 70; 266-278.

Cochran, W.G. 1991. Sampling Techniques. John Wiley and Sons, Inc. Diterjemahkan oleh: Rudiansyah. Edisi Pertama. Penerbit Universitas Indonesia.

[FAO] and [UNEP] Food and Agriculture Organization of the United Nations and United Nations Environment Programme. 1999. The Fulture of Our Land. Facing the Challenge. FAO and UNEP, Rome, Italy.

Gao, F., M. Li., and Y. Nakamori. 2003. Critical Systems Thinking as aWay to Manage Knowledge. Syst. Res 20: 3-19.

Gicheru, P., C. Gachene., J. Mbuvi., and E.Mare. 2004. Effects on Soil Management Practices and Tillage Systems on Surface Soil Water Conservation an Crust Formation on a Sandy Loam in Semi-Arid Kenya. Soil and Tillage Research. 75(2): 173184.

Golar. 2007. Strategi Adaptasi Masyarakat Toro: Kajian Kelembagaan Lokal dalam Pengelolaan dan Pemanfaatan Sumberdaya Hutan di Taman Nasional Lore-Lindu. Disertasi. Institut Pertanian Bogor.

Humberto, B.C., L. Rattan.,and L. Roque.. 2005. Soil Aggregate Properties and Organic Carbon for Switchgrass and Traditional Agricultural Systems in the Southeastern United States. Soil Sience. 170(12): 998-1012

Mappatoba, M., dan A. Laapo. 2001. Usahatani Lahan Kering pada Desa Terpencil di Kecamatan 
Kulawi Kabupaten Donggala. J. Agroland 8 (2): 150-157.

Marimin. 2004. Teknik dan Aplikasi Pengambilan Keputusan Kriteria Majemuk. Penerbit PT Gramedia Widiasarana Indonesia, Jakarta.

Rahman I. 2002. Pengaruh Faktor Sosial dan Ekonomi Terhadap Tingkat Pendapatan Masyarakat Sekitar Hutan. J. Agroland 9 (1): 45-50.

Rauf, R.A. 2004. Analisis Peningkatan Produksi Kakaodi Provinsi Sulawesi Tengah. J. Agrisains 5 (2): 84-90.

Sjarkowi, F. 2007. Pemikiran Konseptual Menuju SUPK (Satuan Usaha Perhutanan Kerakyatan). Jurnal Satuan Usaha Perhutanan Kerakyatan. Jaringan Komunikasi Pasak Bumi. Universitas Sriwijaya. Hal: 1-18

Thaha, A.R. 2001. Studi Erosi Tanah di Kawasan Taman Nasional Lore-Lindu dan Sekitarnya. The Nature Conservancy, Lore-Lindu Field Office, Palu, Sulawesi Tengah.

Widjajanto, D., A. Monde., A. Sudhartono., dan A. Paada. 2003. Studi Air di Daerah Aliran Sungai Gumbasa. J. Agroland. 10: 36-41.

Widjajanto, D., 2006a. Model Penggunaan Lahan Untuk Pengembangan Pertanian Berkelanjutan (Studi Kasus Daerah Aliran Sungai Gumbasa) Disertasi. Institut Pertanian Bogor, Bogor

Widjajanto, D. 2006b. Sistem Pengelolaan Sumber daya Lahan untuk Pengembangan Pertanian Berkelanjutan pada Kawasan Penyangga Taman Nasional Lore-Lindu (Studi Kasus Daerah Aliran Sungai Gumbasa Bagian Hulu). J. Agrokultur. 3(5): 32-42.

Wilts, A. R., D. C. Reicosky., R.R. Allamaras., and C.E. Clapp. 2004. Long-Term Corn Residue Effects. Harvest Alternatives, Soil carbon Turnover, and Root-Derived carbon. Soil Sci. Soc. Am. J. 68: 1342-1351. 